Norway's Arctic diplomatic fix

Poles' defection in Spitsbergen casts shadow

The two Polish scientists who defected last month from the Polish geophysical station at Hornsund (Spitsbergen) have created a delicate diplomatic problem for their Norwegian hosts and something of a crisis for Norwegian Arctic research.

Although sovereignty over Svalbard (the island group of which Spitsbergen forms part) was granted to Norway by international treaty in 1920 , by the same treaty Norway undertook that the nationals of the signatory countries (of whom, with later accessions, there are now 41) should be treated on an equal footing with regard to economic activities.

The Soviet Union thus has two coalmining bases, one near Barentsburg and another at Pyramiden. Similarly, under a memorandum from the Norwegian government to the other signatory states, foreign expeditions have free access to carry out scientific research in Svalbard as well as free access to the information on the islands held by the Norwegian Polar Research Institute.

The Polish research base at Hornsund is staffed by a team of 10 scientists from the Institute of Geophysics of the Polish Academy of Sciences. The research programme includes geological, geophysical, glaciological and meteorological work. A relief expedition, consisting of the 1982-83 scientific team plus a group of technicians to carry out routine maintenance work at the station sailed from Gdynica in July.

On 10 August, two of the scientists (it is not clear whether from the incoming or outgoing teams) decided to ask for political asylum, and radioed the Norwegian Sysselman (governor), announcing their intention to report in person to file their applications at the administrative base at Longyearbyen.

This transmission was, however, picked up by the Soviet Union's mining post at Barentsburg, which sent a helicopter to intercept the two Poles who were repeatedly "buzzed". One was driven back to base while the other fled into the hills and returned to Hornsund next day.

When the Sysselman heard what had happened, he sent out in his own helicopter to pick up the two would-be refugees; the Soviets, however, realized what was happening and sent their own helicopter to try and reach them first. In the words of one Norwegian official, Sysselman won the race, confirmed that the two men still wanted political asylum and took them back with him for questioning to Long-

yearbyen, whence they were dispatched to Oslo for "safe keeping". Their requests for asylum are now being processed; their identities are for the moment being kept confidential.

A number of diplomatic questions remain to be clarified. Military activity on the islands is strictly forbidden under the Svalbard Treaty of 1920; and it could be argued that the Soviet use of their helicopter in what can only be called a third-party police action could be construed as a breach of this agreement.

Furthermore, the Soviet helicopters are supposed to ply only between Barentsburg, Pyramiden and Longyearbyen, while some 44 per cent of Svalbard (including South Spitsbergen, where Hornsund is situated) comes under nature protection orders, where any technological encroachments, including motorized vehicles, are forbidden. Noise harassment of geese and other aquatic birds during the moulting season is particularly hazardous since it can scatter flocks and separate the young prematurely from their parents.

So far, the Norwegian Foreign Office seems concerned to keep the whole incident low-key. For their part, the Soviets can have little wish to fall foul of the Norwegian environmentalists. The Soviet Union extracts some 400,000 tonnes of coal

\title{
Two Soviets banned from Perth
}

\section{Canberra}

The Australian government refused two Soviet scientists visas to attend the 12 th International Congress of Biochemistry in Perth on 15-21 August, organized by the Australian Academy of Science under the aegis of the International Union of Biochemistry (IUB). The scientists are Professor Y.A. Ovchinnikov, vice-president of the Soviet Academy of Sciences who was to deliver a plenary lecture, and Professor S.S. Debov, also a member of the academy. Taking umbrage, the other 25 Soviet registrants boycotted the congress. It now appears that the International Council of Scientific Unions (ICSU) may ban Australia as a venue for international conferences at its meeting on 12 September.

The Soviets singled out for exclusion were regarded by the Australian embassy in Moscow as government men rather than scientists. Consequently the banning is consistent with government policy of not allowing high-ranking Soviets into the country. Following the Soviet invasion of Afghanistan in 1979, the government announced a package of sanctions against the Soviet Union, after a cabinet decision in January 1980. These moves included the suspension of a bilateral scientific and technological agreement signed in 1975, and the banning of mutual visits by ministers and senior officials. A cooperative expedition on a Soviet research ship was called off, Soviet scientists in Mount Stromlo Observatory were sent packing, student scholarships to the Soviet Union were cancelled and visas refused to Soviet agricultural officials. In addition universities were advised to suspend academic exchanges but not multilateral conferences.

After these events, the Australian Academy of Science found itself in the invidious position of having to provide IUB with an assurance that no scientists would be barred. It sought from the government a "form of words" considered to be acceptable to IUB - "bona fide scientists from all countries will be admitted to Australia to attend the conference subject to the normal rules and requirements for visitor entry to Australia in operation at that time." But the then minister for immigration, $\mathrm{Mr}$ Ian MacPhee, wrote to the then foreign secretary of the academy, Professor Gordon Ada, in June 1980 - "I should stress that if this form of words is used, it must be understood by the academy that the normal rules in operation at the time of any conference might well exclude a particular scientist, a group of scientists or scientists of a particular nationality. I could not forecast what would be normal in say 12 months or 3 years time." 
These reservations were not passed on to IUB. Unfortunately the possibility of Soviet scientists being banned as officials was not considered by the organizers at any time during the interim period. A spokesman from foreign affairs believes the problem could have been overcome by consultations beforehand.

The stage was thus set for the imbroglio at the conference, the first IUB congress in Australia. The Soviet participants waited until the last minute to apply for visas, and just a few days before the conference the ban was announced. Appeals from the president of the Australian academy (Professor Arthur Birch), the premier of Western Australia (Mr O'Connor) and the Swedish Academy were all to no avail. It was too late for the government to back off gracefully.

Reactions at the congress were mixed. Professor Frank Gibson of the Department of Biochemistry, John Curtin School of Medical Research, Australian National University, says "disappointment at not hearing Professor Ovchinnikov's lecture was the main reaction'. Lack of travel funds, and the relatively high cost of internal air fares and accommodation limited the number of overseas registrants, particularly from the United States.

The academy now faces the unenviable task of persuading the government to change its policy in the week before the ICSU meeting. Failing this, it will try to delay any precipitate action at the meeting. Nevertheless international censure may be just the prod the government needs to review its policy on sanctions. Significantly, the International Union of Pure and Applied Chemistry succeeded in securing the admission of Israeli scientists into India for a conference on the applications of the Mossbauer effect held in Jaipur last December. Vimala Sarma

\section{European space technology Ariane set to go}

The delay to the fifth launch of Ariane, rescheduled from last April to tomorrow, has had its effects on the vehicle's future launch programme. But careful reorganization of the launch schedule up until the end of 1984 seems to have ensured minimal damage to the launcher's commercial prospects.

The five month delay has been caused by problems with Marecs B, one of two satellites that the fifth Ariane will put into geostationary orbit. Marecs $\mathbf{B}$ had to be modified after problems with electrostatic charging on Marecs A, the sister satellite launched by the fourth Ariane late last year. The first effect of the delay has been to reduce the number of Ariane launchers this year from four to two. The next launch now scheduled for November will put Exosat, the X-ray observatory built by the European Space Agency, into polar elliptic orbit, more or less on its target date. But the launch of ECS 1, a communications satellite, is being delayed to early next year and Intelsat, the international telecommunications satellite organization, which was to have launched the sixth Intelsat $\mathrm{V}$ satellite aboard Ariane in October or December this year, has taken that part of its custom elsewhere.

Intelsat, however, has not reduced its overall commitment to Ariane. The launcher will now put Intelsat $\mathrm{V}$ numbers 7 , 8 and 9 into orbit next year instead of numbers 6,7 and 8. Next year's launch programme has been rescheduled to include six launches, the maximum possible with the present launch pad, instead of five originally planned.

Ariane is now fully booked with firm orders until the end of 1984 , according to

\section{Now even MIT has troubles}

\section{Washington}

Even well-off US universities are not immune from the financial squeeze affecting US higher education. The Massachusetts Institute of Technology (MIT), which has an operating budget of $\$ 500$ million, reports that it had a deficit of $\$ 2$ million for the year just ended. Next year's deficit could be $\$ 4$ million. Consequently, it has now announced plans to cut costs and, among other things, to lay off 400 employees.

Unlike both the California Institute of Technology and Stanford University, with which MIT is often compared, MIT has a relatively small endowment and thus a harder cushion for hard times. The current deficit is not MIT's first; it had a deficit in the early 1970s, when it lost the extra income and overhead funds that went with the Charles Stark Draper Laboratory, from which it severed its connections at that time.

According to provost Francis E. Low, approximately two-thirds of MIT's operating budget is composed of funds that come in each year to operate facilities such as the Lincoln Laboratory, with little control or financial benefit to the rest of the institute. To control rising costs, then, the institute must look to the $\$ 120$ or $\$ 130$ million in general funds that pay for education and its administration. To prevent rising deficits, these activities will have to be reduced. There will be some faculty reduction through normal attrition, causing a loss of approximately 30 positions. Also, 200 other people will be allowed to leave through attrition in the next few years, he says, while an additional 200 will be laid off. Low thinks the institute can afford some belt-tightening: "It [MIT] functions in some respects in a luxurious way". Deborah Shapley
Arianespace, the company that will take over commercial operation of the launcher some time next year. Just two places remain to be firmly negotiated for 1985 and a number of reservations, for which customers must pay $\$ 100,000$, are apparently in hand for future years. But Ariane has now lost some early reservations from customers who have eventually plumped for US facilities and Arianespace acknowledges that the fifth launch of the shuttle in November, which will put a satellite into geostationary transfer orbit, could take the edge off Ariane's seeming attractiveness.

The next few Ariane flights will still be formally in the hands of the European Space Agency. Arianespace will take over operations and start earning revenue from launches from the middle of next year, probably after the tenth flight. The company hopes that by 1985 the capacity of the launch facilities at Kourou in French Guiana will increase from 6 to 12 when the second launch pad, now under construction, comes into operation. Arianespace expects to start showing a modest but respectable profit in 1985. But future prospects will also depend on the success of the space shuttle. The latest estimate is that customers will have little to choose between the two on price. Reliability, service and convenience could be most significant.

Judy Redfearn

\section{Australian science politics}

\section{Labor's policy \\ Canberra}

The Australian Labor Party, more hopeful than ever that it will form the next federal government but less certain now than a few weeks ago that the general election will come soon, formally adopted a new policy on science and technology at its biennial conference here in July. Although the policy is vague enough not to be a constraint on Labor members of parliament, the convention that conference decisions are binding on elected representatives may yet cause trouble.

The new science policy was adopted on the nod on the last day of the conference, when most delegates were packing up to go home. On the face of things, science and technology have only low priority, at least compared with the uranium issue. The conference heard a sustained and embittered debate on the question of whether Australia under Labor would honour existing uranium contracts. That issue remains unresolved, although the conference confirmed the principle that Labor will supply uranium abroad only on tough conditions.

The cornerstone of the Labor Party's policy on science and technology is economic - government spending will bring prosperity and economic growth. Mr William Hayden, the leader of the party, and his colleague with responsibility for 